\author{
ECONOMIC GROWTH IN THE MID ATLANTIC REGION: \\ CONJECTURAL ESTIMATES FOR 1720 TO 1800 \\ Joshua L. Rosenbloom \\ Thomas J. Weiss \\ Working Paper 17215 \\ http://www.nber.org/papers/w17215
}

\author{
NATIONAL BUREAU OF ECONOMIC RESEARCH \\ 1050 Massachusetts Avenue \\ Cambridge, MA 02138 \\ July 2011
}

This research was funded in part by the National Science Foundation Grant SES-0317265. The views expressed herein are those of the authors and do not necessarily reflect the views of the National Bureau of Economic Research.

NBER working papers are circulated for discussion and comment purposes. They have not been peerreviewed or been subject to the review by the NBER Board of Directors that accompanies official NBER publications.

(C) 2011 by Joshua L. Rosenbloom and Thomas J. Weiss. All rights reserved. Short sections of text, not to exceed two paragraphs, may be quoted without explicit permission provided that full credit, including (C) notice, is given to the source. 
Economic Growth in the Mid Atlantic Region: Conjectural Estimates for 1720 to 1800

Joshua L. Rosenbloom and Thomas J. Weiss

NBER Working Paper No. 17215

July 2011, Revised March 2013

JEL No. N1,N11,N71,N9,N91,O19

\begin{abstract}
$\underline{\text { ABSTRACT }}$
We employ the conjectural approach to estimate the growth of GDP per capita for the colonies and states of the mid-Atlantic region (Del., NJ, NY and Penn). In contrast to previous studies of the region's growth that relied heavily on the performance of the export sector, the conjectural method enables us to take into account the impact of domestic sector, in particular the production of agricultural products for the domestic market. We find that the region experienced modest growth of real GDP per capita. Although the rate of growth was modest in comparison to what would materialize in the late nineteenth century, it was faster than that of the Lower South in the eighteenth century, and at times as fast as that for the U.S. in the first half of the nineteenth century. In its heyday of growth from 1740 to 1750 -before the dislocations produced by the spread of the Seven Years' War--real GDP per capita rose at 0.7 percent per year, driven by the growth of output per worker in both agriculture and nonagriculture, and by capital accumulation.
\end{abstract}

Joshua L. Rosenbloom

Department of Economics

University of Kansas

Snow Hall 436

1460 Jayhawk Blvd

Lawrence, KS 66045-2113

and NBER

jrosenbloom@ku.edu

Thomas J. Weiss

Department of Economics

University of Kansas

Lawrence, KS 66045

and NBER

t-weiss@ku.edu

An online appendix is available at:

http://www.nber.org/data-appendix/w17215 


\section{Economic Growth in the Mid Atlantic Region: Conjectural Estimates for 1720 to 1800}

Understanding when and how modern economic growth, characterized by sustained improvements in per capita income, began remains one of the central concerns of economic history. In Western Europe and North America, the transition to modern economic growth was clearly underway by the early nineteenth century. It remains difficult, however, to be much more precise about the timing of the transition without better estimates of aggregate economic growth in the eighteenth century. ${ }^{1}$ In recent years considerable progress has been made in leveraging new data and new perspectives to illuminate the long-run performance of the English economy, although how to interpret these data remains in dispute (see, e.g., Clark 2013 and Broadberry et al 2013). ${ }^{2}$ In contrast, relatively little attention has been given in recent years to refining our understanding of the performance of the American economy prior to 1800 , and there is considerable variation (as we document below) in the prevailing views about this period. While it is tempting to seek a single set of estimates for all of the territories that became the United States after 1776, the varied nature of regional economies and the limited scope of economic integration across regions suggest that it may be more useful to build such estimates region by region. $^{3}$

\footnotetext{
${ }^{1}$ As Leunig (2013, p. 1) writes: "Discovering what has happened to national income over the very long run is an extremely important issue in economic history. It is the essential first step to understanding why and how modern economic growth emerged

${ }^{2}$ Improving on estimates of pre-1820 economic growth is a central objective of the recently announced Maddison Project (Bolt and van Zanden 2013).

${ }^{3}$ Lindert and Williamson (2011) take a regional approach in their recent work on the period 1774-1840. A regional approach has the advantage that some relevant data are available only for one or a few regions.
} 
In what follows we offer new estimates of the aggregate performance of the Middle Atlantic region (modern-day New York, Pennsylvania, Delaware, and New Jersey) between 1720 and $1800 .^{4}$ In contrast to the most widely accepted estimates, which suggest that the region and all of what became the United States experienced sustained improvements in material living standards over the course of the eighteenth century, we demonstrate that there was relatively little long-run improvement prior to 1800 , and that any such progress was dwarfed by shorter-run instability in income. While this finding implies that the onset of modern economic growth in this region of North America did not occur prior to 1800, it also emphasizes the comparatively high standard of living that was enjoyed on average by its residents in the eighteenth century, and the striking ability of the regional economy to sustain this standard of living while undergoing very rapid extensive growth. ${ }^{5}$

Considerable evidence supports the view that residents in all regions of eighteenthcentury British North America enjoyed a high standard of living, and this prosperity attracted continuing streams of immigrants, encouraged a high birth rate, and fostered investment in slave and indentured labor; all of which combined to generate one of the highest rates of growth of population in the world at the time. Abundant land forestalled diminishing returns so that the high rate of population growth was also transformed into a high rate of growth of gross domestic product and its components, including exports. The levels of wealth achieved by some free colonists were high and had increased over the colonial period. The average stature of those born in the colonies, and thus able to benefit from the cornucopia of produce and the more

\footnotetext{
${ }^{4}$ We use the regional definition followed by most colonial historians and include Delaware because it was part of New Jersey during the colonial period. The current Census definition would put it in the South Atlantic region.

${ }^{5}$ Smith (1981) makes clear that not everyone enjoyed this relatively high standard of living.
} 
favorable environment than that in Europe, increased noticeably (Komlos, 2001; Steckel 2002, Table 3). As John McCusker (2006, p. 630) put it in his survey of colonial statistics, "On the eve of the American Revolution, real per capita gross domestic product in the Thirteen Continental Colonies was: ... higher than any other nation in the world at the time."

In contrast to the consensus that exists about the standard of living in the colonies and about aggregate growth, there is considerably less agreement about the rate of growth of living standards and per capita GDP. Despite McCusker's assertion "that its economy grew at the fastest rate of all known contemporary economies," scholars remain divided about the actual rate of economic growth as illustrated in the range of estimated growth rates reported in Table 1. Most of the estimates for the mainland Anglo-American colonies as a whole fall between 0.3 percent and 0.6 percent per year, but scholars have placed the rate of growth of real GDP per capita anywhere between 0.05 to 1.0 percent per year. ${ }^{7}$ The lower rate implies that however successful the economy might appear to have been, it was a static prosperity. The higher rate means that the colonial economy performed on average - over a very long period of time - better than the U.S. economy performed in the first half of the nineteenth century, an age which witnessed the industrialization of the northeast, the expansion of railroads and canals, and more

\footnotetext{
${ }^{6}$ He also alleged that it was "higher by far than it had been a century or a century and a half earlier," the result of his having assumed a "long-term rate of growth [that] exceeded, perhaps even doubled, the rate of growth of Great Britain."

7 McCusker (2000, p. 156, Tables 1 and 2, and accompanying text) argued that the weight of opinion would narrow this range to between 0.3 and 0.6 percent per year. For an earlier argument in favor of this range, see also McCusker and Menard (1984, pp. 52-57) where they argued that the lower bound of colonial growth was established by estimates (at the time) of the rate of growth in England, while the higher rate reflected their view that because the colonies had started out far behind they likely grew faster than the mother country. McCusker (2000, p. 5) reaffirmed the view that "the long term rate of growth exceeded, perhaps even doubled, the rate of growth of Great Britain."
} 
broadly the acceleration of economic growth to modern rates. It is also important to note, that since the estimated level of GDP per capita in 1800 is widely accepted (see Table 2 below, Lindert and Williamson, 2011, Table 6, and McCusker, 2000, Table 2), the more rapid the rate of growth supposed to have prevailed in the preceding decades, the lower the standard of living must have been at the beginning of the period.

The range of rates is even more pronounced for individual colonies and regions reported in the bottom half of Table 1, ranging from minus 0.8 percent per year for New England from 1700-09 to 1770-79 to 1.6 percent per year for Pennsylvania between 1730 and 1770. Lindert and Williamson (2011, Table 6) report an equally broad range of growth rates across regions for the period 1774 to 1800 . A range of opinion on the speed of economic growth is to be expected given the divergent nature of the economies of the various colonial regions and the relative paucity of quantifiable data for the period, but some of the variation may reflect the methods of estimation. In the absence of comprehensive statistics, past efforts to measure colonial economic performance have relied on the behavior of what each individual researcher thought of as either the key economic variable or what they were able to measure, thus ignoring some possible countervailing influences. ${ }^{8}$

Refining our understanding of the dynamics of economic growth in North America before 1800 requires moving beyond estimates based on a single variable or the impressionistic combination of several key indicators. A more systematic approach to integrating the available data is needed, and the method of controlled conjectures provides exactly this. Exports, which comprised roughly 6-8 percent of the economy, are only a part of the conjectural estimates rather

\footnotetext{
${ }^{8}$ Alice Hanson Jones (1980), for example, used changes in wealth and an assumption about the likely ratio of wealth to income to estimate GDP. Marc Egnal (1998, Table 3.6, p. 43) explained that to arrive at his estimates "initial approximations were derived from data on per capita imports."
} 
than serving as a proxy for the entire economy's performance. Likewise our approach takes into account the influence of increased wealth, 60 percent of which in the Mid Atlantic was the value of real estate. In other words, this method allows us to produce estimates of GDP per capita that are consistent with all of the available evidence, while making explicit the assumptions we use in assembling these different components. And, importantly, this method allows us to assess the consistency of other estimates with the available evidence.

The initial application of the conjectural method to the colonies as a whole by Mancall and Weiss (1999) suggested that the rate of growth of per capita GDP was substantially slower than had been commonly accepted. Such a result for all the colonies need not, however, reflect the performance in any specific region, especially given the extraordinary divergence in the economic systems of the mainland British colonies. Growth rates for New England, which had no large-scale staple exports, might have differed dramatically from the rates in plantation regions of the Chesapeake colonies or the Lower South, or even the grain-exporting sectors of the middle colonies. Moreover the evidence available varies from region to region. Thus, more precise estimates of growth rates during the colonial period need to come from analysis of specific regions.

Here we employ the conjectural approach to develop estimates of the growth of GDP per capita for the colonies and states of the mid-Atlantic_-modern-day New York, Pennsylvania, Delaware, and New Jersey . ${ }^{9}$ Our earlier analysis of the economy of the Lower South (Mancall, Rosenbloom and Weiss 2003) revealed that the region, despite its extensive rice and indigo exports, had a poor record of intensive economic growth. Exports and output (i.e. real GDP)

${ }^{9}$ We use the regional definition followed by most colonial historians and include Delaware because it was part of New Jersey during the colonial period. The current Census definition would put it in the South Atlantic region. 
grew quite rapidly, but so too did population, with the result that output per person at the end of the colonial period, as well as at the end of the century, was virtually the same as it had been in 1720 - around \$59-60 (in 1840 prices). The region experienced some very modest growth between 1740 and 1770, but that could not offset periodic declines in GDP per capita before 1740 and after $1770 .^{10}$

Until now, there has been no similar analysis of the middle colonies, though a number of previous histories have speculated about the region's economic performance, arguing that it experienced sustained growth with trade as the driving factor for regional economic fortunes. ${ }^{11}$ Summing up much of the scholarship about this region, McCusker and Menard (1984, p. 202) concluded that "commencing in the 1720 s, a long, powerful, sustained expansion characterized the remainder of the colonial period, with perhaps some (but not much) tailing off after 1760."12 Marc Egnal (1998, p. 46), though differing in some details, also offered a sanguine assessment of the region's growth, noting that while the pace of development was uneven, "[s]olid long-term growth marked the northern colonies in the eighteenth century."

Presumably, results for this region would differ from the Lower South, at least in part because the Middle Atlantic's exports of grains figured less prominently in the regional economy

\footnotetext{
10 The absence of growth in per capita output in the Lower South reflects to a large extent the changes in the composition of the population, namely a rise in the share of the female and child shares of the population, and after 1770 a decline in the slave share of the population, all of which served to reduce the labor force participation rate.

${ }^{11}$ In some sense, the field has not evolved substantially - at least not in terms of precise quantifiable estimates, for the past thirty years-since the time when Greenberg (1979, pp. 410-11), suggested that "economic growth and the social change and dislocation that often accompanied it occurred, in the main, more rapidly in New York, New Jersey and Pennsylvania than elsewhere in North America during the colonial period."

${ }^{12}$ McCusker (1972, p. 155, fn 17) argued that economic growth in Pennsylvania proceeded at the astonishing rate of 1.6 percent per year between 1730 and 1770 .
} 
than did the Lower South's staple exports of rice and indigo. Further, though there were slaves in the middle colonies, they constituted a far smaller and declining share of the overall population, most likely because farmers involved in cereal cultivation did not have year-round demand for labor (Berlin, 1980). Instead, the family or tenant farm dominated the regional production of wheat and corn. While the majority of these agricultural products were consumed locally, nonetheless the region exported a considerable quantity of these grains, primarily to the West Indies and Southern Europe. Yet, to determine what actually happened, we must look at the available evidence.

Our estimates reveal a modest upward trend in regional per capita income between 1720 and 1800 along with substantial short-run fluctuations. In the half-century preceding American independence, per capita income increased at an average annual rate of about 0.13 percent per year. But that long-run average increase was dwarfed by short-run swings in income. During the 1750s, for example, the stimulus provided by the French and Indian War contributed to a nearly 8 percent increase in per capita income, but the dislocations that followed when it ended wiped out almost all of those gains. And incomes fell sharply in the wake of the American Revolution, before staging a substantial comeback in the 1790s which reflected the boom in the export and re-export trade. These figures suggest that to contemporaries the dominant fact of the aggregate economy must have been its short-run volatility rather than any trend toward sustained improvement in living standards. They also suggest, consistent with new work by Lindert and Williamson (2011), that the Revolution produced a substantial drop in American incomes that persisted until the early 1790s. 


\section{Using Controlled Conjectures}

Our estimates of per capita GDP growth for the states and colonies of the middle Atlantic region are derived using the conjectural estimating equation pioneered by Kuznets (1952), popularized by David (1967), and modified by Weiss (1994). Output per person (GDP/P) in any year equals the product of the labor force participation rate (LF/P) and average (non-shelter) output per worker (GDP/LF), plus an estimate of the rental value of dwellings. ${ }^{13}$ Output per worker can, in turn, be written as a weighted average of output per worker in agriculture (a) and nonagriculture (n), where the weights are each sector's share of the labor force. Thus the basic estimating equation can be written as:.

$$
\mathrm{GDP} / \mathrm{P}=(\mathrm{LF} / \mathrm{P})\left[\mathrm{S}_{\mathrm{a}}(\mathrm{O} / \mathrm{LF})_{\mathrm{a}}+\mathrm{S}_{\mathrm{n}}(\mathrm{O} / \mathrm{LF})_{\mathrm{n}}\right]+\left(\mathrm{O}_{\mathrm{s}} / \mathrm{P}\right)
$$

Because $S_{n}=\left(1-S_{a}\right)$, the equation can be further simplified to:

$$
\mathrm{GDP} / \mathrm{P}=(\mathrm{LF} / \mathrm{P})\left[\mathrm{S}_{\mathrm{a}}(\mathrm{O} / \mathrm{LF})_{\mathrm{a}}+\left(1-\mathrm{S}_{\mathrm{a}}\right)(\mathrm{O} / \mathrm{LF})_{\mathrm{n}}\right]+\left(\mathrm{O}_{\mathrm{s}} / \mathrm{P}\right)
$$

As equation (2) makes clear the value of per capita GDP in any year can be computed with data for just five economic variables: the labor force participation rate, average labor productivity in agriculture, average labor productivity in nonagriculture, the agricultural share of the labor force, and the rental value of dwellings. Of course, we do not have data for all five of these variables, so we must estimate some of them, as we detail below.

Our estimation procedure proceeds backward in time: the benchmark estimate of the level of each series in 1800 is projected backwards on the basis of the available evidence and plausible

\footnotetext{
${ }^{13}$ While the stock of dwellings would have been produced by labor, the annual flow of shelter services was produced by the housing stock. Thus we treat this service flow independently from the bulk of output produced by labor so that it does not bias changes in the output per worker values in either agriculture or nonagriculture. See Weiss (1994, Table 5) for evidence on the bias that was involved in the period from $1840-60$.
} 
conjectures. $^{14}$ We proceed as if the benchmark figures are known values, even though they are not known with the precision or completeness of official statistics. Rather, they are estimates taken from the work of others and were not generated by our conjectures. ${ }^{15}$ In any case, these are the benchmark values that we extrapolate backward on the basis of the change in the conjectural index. These base-year values of output per capita and its components for the region are summarized in Table 2 and compared to values for the nation as a whole.

To obtain estimates of per capita GDP for years before 1800 we constructed a time series for each of the variables that make up the conjectural estimating equation. Three of the series could be constructed in a fairly straightforward manner because there exists time series evidence for key items that underlay that series (e.g. population and its composition, which form the basis of the labor force estimates) or that could serve as a proxy for the desired series (e.g. change in the value of structures to represent change in the value of dwellings that yielded the annual flow of shelter services). Discussion of those series is confined to the table notes and the appendix to this paper. Here we discuss the two series, output per worker in agriculture and in nonagriculture, that required more effort to construct and are the most important influences on the economy's rate of growth. Three pieces of information or assumptions lie behind these important series: the rate of change in the value of the diet (which is the dominant factor in determining the rate of growth of agricultural output and thus agricultural output per worker); the

${ }^{14}$ We use the 1800 figures as our benchmark because there is as yet no reliable estimates of the level of economic performance in the colonial period. Lindert and Williamson's (2011) work in progress, should eventually rectify this situation. Their preliminary estimate of per capita income for the Mid Atlantic in 1774 of $\$ 76$ (in 1840 prices) is very close to the value (\$78) we estimate for 1770 .

15 The GDP per capita figures in 1800 for the region were based on the national estimates by Weiss, (1992, Table 1.4). David's, (1967) estimates for 1800 are lower than Weiss's and thus dictate less potential for growth in the preceding century. In both cases, the figures were conjectured in ways that leave the 1800 figures unbiased by business-cycle influences. 
assumption that changes in real wages of urban workers can approximate changes in nonagricultural output per worker; and the rate of change of participation in the rural agricultural labor force.

\section{Estimation of Agricultural Output}

Measuring agricultural output is essential to constructing plausible estimates of the rate of growth of per capita GDP before 1800 because agriculture was the dominant component of the economy. At the end of the century, agricultural output comprised 41 percent of the region's GDP and 45 percent of non-shelter output (Table 2). No time series of the region's agricultural output is available for the eighteenth century, but we were able to construct one in fairly direct fashion. The output of the agricultural sector is comprised of food that was produced and consumed within the region (f) and those agricultural products that were exported either abroad $\left(\mathrm{x}_{\mathrm{a}}\right)$ or to other colonies $\left(\mathrm{x}_{\mathrm{o}}\right){ }^{16}$

$$
\mathrm{O}_{\mathrm{A}}=\mathrm{f}+\mathrm{x}_{\mathrm{a}}+\mathrm{x}_{\mathrm{o}}
$$

Food produced for domestic consumption within the region (f) was the largest component of agricultural output in the colonies. Because of its importance we describe the estimation here

\footnotetext{
${ }^{16}$ We treat all this agricultural output as though it were marketed in order to place a value on it and to make our estimates comparable in scope to those for the early part of the nineteenth century. We have not made estimates of the value of home manufacturing and farm improvements in each year, but the value of some of that production is implicitly included in our estimates to the extent that such production had become part of the marketed output in the benchmark year of 1800. In other words, the level of our GDP series includes some of this output, but changes in these items over time do not have an impact on the rate of growth. Because these items were likely more important in 1720 than in 1770 or 1800, the inclusion of a time series of such output would raise the level of GDP in all years, but more so in 1720, and would thus bias downward the estimated rate of economic growth.
} 
in some detail, and in greater detail in the appendix to this paper. We have compiled a new and more complete time series on agricultural exports from the region, both to foreign markets $\left(\mathrm{x}_{\mathrm{a}}\right)$ as well as to other North American colonies $\left(\mathrm{x}_{\mathrm{c}}\right)$, both of which are described in a separate publication and the appendix to this paper. ${ }^{17}$

We estimated food produced for domestic consumption within the region (f) as the difference between the value of food consumed (c) and the value of food imported into the region from abroad $\left(f_{m}\right)$ as well as from other North American colonies $\left(f_{o}\right)$. In other words,

$$
f=f_{c}-f_{m}-f_{o}
$$

There is no time-series evidence on consumption, but by using the available information about the diets of colonists and slaves we estimated the trend in the value of food consumed with which we derived values at benchmark dates from 1720 to 1800 .

The lower bound for the trend would seem to be no growth in the value of the diet. There is no credible evidence that the value of the diet declined over time, while there is evidence that military rations, the value of provisions provided to troops in New York and Pennsylvania, stayed roughly constant. ${ }^{18}$ And, data on the wages of working class laborers in Philadelphia indicate that while there were short-run fluctuations in earnings there was likely no long-term change in the standard of living for those workers. Real wages may have fallen at times during the colonial period, but were roughly equal in the late 1720 s and $1800 .{ }^{19}$

\footnotetext{
17 See Mancall, Rosenbloom and Weiss (forthcoming)

${ }^{18}$ Gallman, (1971, pp. 71-78), argued that the militia were ordinary members of society serving in the military for a temporary period of time, so military rations seem like a reasonable proxy for food consumption by the colonists.

${ }^{19}$ Nash (1979, pp. 392-94). We extended Billy G. Smith's cost of living index back to 1727 in order to deflate the nominal wages reported by Nash. Smith (1981, pp. 164-202). The 1800 figure was lower than that of 1727-28, but the average for 1798-1800 was about the same as that for 1727-28
} 
The upper bound on the growth of the diet was determined by comparing our benchmark estimates for 1800 (see Table 2) and evidence on the composition of the diet found in the Rules for Georgia, which specified, in some detail, the provisions to be provided to persons on charity who were transported to that colony in the 1730s (Candler, 1904-16, vol. 3, pp. 408-9). Although this information on the diet pertains explicitly to colonists in Georgia, it nevertheless provides a point of reference for free colonists elsewhere. ${ }^{20}$ The specified diet included beef or pork, rice, peas, flour, beer, molasses, cheese, butter, spice, sugar, vinegar, and salt. Moreover, quantities of each category of provisions were specified for adult males, adult females, children, and servants. We have calculated that the weighted average value of these provisions for free colonists in prices of 1840 amounted to $\$ 24 .^{21}$ Because this figure is approximately the same as the value other scholars have imputed to food consumed by slaves in 1800 , and because it reflects an estimate of the food consumed by those on charity in a newly formed colony that was much less advanced economically than New York or Pennsylvania we have taken it as a lower bound on the value of per capita food consumption for the average free colonist in the more developed Mid-Atlantic region in the 1730s.

Taken in conjunction with the given value of the diet in 1800 (see Table 2), this lower bound value for 1730 yields a very high upper bound on the rate of growth of the diet of 0.37 percent per year over the period, and one that we believe to be implausibly high because it is

\footnotetext{
20 The little data available on the value of the diet for charity cases in the Middle Colonies do not yield enough useful information about the trend in consumption. See, Philadelphia (1802) and Parker (1975, p. 5)

21 The diet for women and children aged 12 and over was 83 percent that of a male; that for children aged seven to twelve was half that for those aged 12 and over; and that for those aged two to seven was onethird. No provisions were provided for those under two years of age (Candler, 1904-16, vol. 3, pp. 40809).
} 
unlikely that European colonists in the Mid Atlantic enjoyed a diet in 1720 equivalent to that of slaves in 1800. . It is difficult to reconcile such a low value of the diet in 1720 with the MidAtlantic region's strong attraction for settlers. Thus the value of the initial year's diet had to have been higher and the rate of growth thereafter must have been slower. Beginning with the known value of the diet in 1800 , if the trend rate of growth in the diet had been only 0.2 percent per year, the implied value of food consumption per capita in 1720 would have been a more plausible value of $\$ 27$, about 15 percent above the value of the slave diet. Even so, this figure still seems too low to have induced as much immigration and natural population growth as occurred in the eighteenth century. The implied trend in the growth of the value of the diet of 0.2 percent per year is likely still biased upward, but nevertheless can serve as an upper bound. ${ }^{22}$

We are confident therefore that the long term average growth rate of the value of the diet between 1720 and 1800 lies somewhere between 0 and 0.2 percent per year, and our baseline estimate is simply the midpoint of this range- 0.1 per cent per year. ${ }^{23}$ This trend in the growth of the diet was used to extrapolate the 1800 benchmark value of food consumed back to $1720 .^{24}$

${ }^{22}$ In the appendix, we show that the rates of growth in agricultural output per worker implied by different rates of growth in the diet suggest that 0.2 is a more realistic upper bound.

${ }^{23}$ We also assumed that the slave diet changed at the same rate as that for the average colonist. Because slaves were relatively unimportant in the region, averaging less than 7 percent of the population for the entire period and dwindling in importance over time, this has little bearing on the growth of GDP per capita for the entire population. Had we assumed the slave diet had remained unchanged, GDP per capita would have risen slower by 0.005 percent per year. If we assumed the slave diet had risen twice as fast, GDP per capita would have increased faster by only 0.006 percent per year.

${ }^{24}$ As we show below the plausibility of our assumption about the rate of growth in the value of the diet is reinforced by the implied rate of growth of agricultural labor productivity that it generates. 
We then deducted estimates of the import of food from both foreign nations and other North American colonies from the benchmark estimates of food consumed to obtain the estimate of food produced within the region for consumption within the region. ${ }^{25}$

The components of agricultural output are summarized in Table 3. Regional consumption of agricultural products and the related regional production comprised the bulk of agricultural output. The production of food supplied over 90 percent of food consumed within the region during the colonial period, and amounted to 85 percent of total agricultural output. ${ }^{26}$ The remainder of the consumption was supplied by imports from abroad and from other North American colonies. The former supplied about 5 percent of consumption, while imports from other colonies accounted for 3 to 4 percent. The share of consumption supplied by imports from abroad was higher after 1790 than it had been during the colonial period, and that supplied by other states was noticeably higher in 1800 , but still food imports in total amounted to only 10 percent of food consumption in the region. In other words, the region supplied the bulk of its food consumption.

Agricultural exports abroad and to other colonies appear to have been a positive force for growth over both long-term periods, with the per capita values having risen at 0.49 percent per year from 1720 to 1770 and 0.54 from 1720 to 1800 . It is striking, however, that it was the export of agricultural products to other North American colonies that was the more positive

25 The construction of the time series on food imported from abroad and from other North American colonies is described in the appendix to this paper.

26 The rate of growth of food consumed per capita differs from the 0.1 percent growth rate we have assumed for the diet of free colonists because of shifts in the composition of the population. The relative level of consumption of free adults is higher than that of children, and that of free colonists is higher than that of slaves. Declines in the slave share of the population raise the weighted average and its rate of growth, while increases in the child share of the population lower the weighted average and rate of growth. 
influence at times. Exports abroad on a per capita basis rose at 0.36 percent per year from 1720 to 1770 , but declined at 0.07 percent per year from 1770 to 1800 , while exports per capita to other colonies rose at 0.8 percent per year during the colonial period and 1.1 percent per year after 1770. The latter were a smaller share of exports for most of the period, but by 1800 exports to other states were about equal to shipments to foreign destinations. Although exports, both abroad and to other colonies and states, grew substantially, they comprised a much smaller share of the agricultural sector than did food produced for domestic consumption, amounting to around 11-13 percent, except in 1800 when they comprised about 17 percent. Nevertheless, in most decades there growth was strong enough to propel the sector's output at a faster rate than that exhibited by the sluggish growth of locally consumed food production.

Combining the various elements of agricultural production we find that agricultural output per capita rose during the colonial period at 0.18 percent per year, declined noticeably between 1770 and 1790, and recovered most, but not all, of those losses in the 1790s. Over the entire period 1720 to 1800 , growth in the per capita value averaged 0.07 percent per year. Output per worker fared slightly better because the agricultural labor force grew more slowly than population after $1790 .{ }^{27}$ Over the colonial period, output per worker in agriculture rose at 0.19 percent per year, then accelerated slightly after 1770 , and advanced for the entire period 1720 to 1800 at 0.25 percent per year.

\footnotetext{
27 The small decline in the agricultural share of the labor force reflects a very gradual decline in the rural agricultural participation rate of 0.07 percent per year, described further below.
} 
These growth rates of agricultural output per worker are consistent with several pieces of evidence regarding the performance of the agricultural sector. ${ }^{28}$ One is the growth of output per worker in the early nineteenth century, which defines a likely upper bound on the growth of output per worker over long periods in the eighteenth century. ${ }^{29}$ A second is the productivity growth implied by changes in the length of indentured servant contracts, the modal value of which suggests little if any gain before 1760 and some increase in servant value after $1770 .{ }^{30}$ And finally, our estimated rates of growth of output per worker are very similar to those estimated by Ball and Walton for Chester county, Pennsylvania, the only other estimate of output per worker we have been able to find that pertains to the eighteenth-century Middle Atlantic region. Our estimated rates of change in output per worker -0.19 percent per year from 1720 to 1770 and 0.25 per year from 1720 to 1800 - are very close to the 0.19 percent per year rate Ball and Walton found for the period running from $1714-31$ to $1775-90 .{ }^{31}$ Overall, we think these comparisons indicate that our implied rates of growth of output per worker are very reasonable and lend credence to our assumption that the value of the diet rose at 0.1 percent per year and to our estimates of agricultural output.

\footnotetext{
28 The appendix to this paper contains more detailed comparisons of our rates of growth of agricultural output per worker with these other bodies of evidence.

29 This point was made by Ball and Walton (1976, p. 103). There could be a decade now and then in which there was an upsurge in output per worker, but over an extended period of time the growth in output per worker in the eighteenth century could not have exceeded the average increase over long periods in the nineteenth century.

${ }^{30}$ Grubb (1992, pp. 181-82 and 202-25) argues that the mode is the superior measure of changes in the contract length and the value of adult servants because the mean values were influenced by yearly fluctuations in the age structure of emigrant servants.

${ }^{31}$ Ball and Walton, (1976,pp. 109-113, Table 3). In the appendix we show that even over shorter time periods our rates of growth are very similar to those they found. The growth of agricultural output per worker in the region over this long term also compares favorably with our estimate for the Lower South. For that region we estimated that output per worker rose at 0.22 percent per year from 1720 to 1800 . Mancall, Rosenbloom and Weiss (2003, p. 403).
} 


\section{Estimation of Sectoral Shifts and non-Agricultural Labor Productivity}

In addition to our conjecture about the rate of growth of the value of the diet, which is embedded in the resulting estimates of output per worker in agriculture, our estimates of GDP per capita depend on two other time series; the agricultural share of the labor force and nonagricultural output per worker. Changes in the latter influence directly overall output per worker, and, since the level of nonagricultural output per worker is greater than that in agriculture, redistribution of labor between sectors indirectly affects overall output per worker.

Estimates of the agricultural share of the labor force are based on two factors; changes in the urban-rural composition of the population and the rate at which the agricultural share of the rural population changed over time. Due to the growing importance of New York and Philadelphia to both trans-Atlantic and regional trade, the urban population of the Mid Atlantic region increased more than eight-fold between 1720 and 1800. However, reflecting the region's bountiful agricultural opportunities, total regional population grew even more quickly: rising by a factor of nearly 14. As a result, the urban share of population fell from 16.5 percent in 1720 to 9.8 percent in $1800 .^{32}$ Because the agricultural share of the urban labor force was so much smaller than that of the rural areas, this shift worked to increase the agricultural share of the region's labor force. ${ }^{33}$

\footnotetext{
${ }^{32}$ In addition to the positive attractions of agriculture, Lindert and Williamson (2011, p. 26) attribute the decline of urban population in the last quarter of the century to the negative effects of the Revolution and independence on urban occupations.

33 If the urban share of the population had remained constant at 16.5 percent from 1720 onward, the agricultural share of the region's labor force would have been lower by 2 to 5 percentage points.
} 
Offsetting the relative decline in the population of the largest cities was the growth of non-agricultural employment in rural areas and small towns. Based on data from Ball and Walton (1976) for Chester County, PA we have estimated a decline in the rural agricultural participation rate of 0.07 percent per year, which reduced the agricultural share of the rural labor force from 0.85 in 1720 to 0.77 in 1800 . Taken together, the decline in the urban population and the movement of rural labor out of agriculture resulted in the long-run in a nearly stable sectoral distribution of the labor force. Between 1720 and 1740 the agricultural share of the labor force increased from 0.71 to 0.74 , and then, as urban growth accelerated the share fell through the end of the century, reaching 0.70 by 1800 .

The impact of these sectoral shifts depends on the difference between agricultural and non-agricultural output per worker. Although nonagricultural output per worker was nearly 3 times that in agriculture, the shift into the more productive nonagricultural sector was so small that it had very little impact on output per worker and output per capita.

Given the smaller share of the non-agricultural labor force in the economy, it would be difficult for any growth in labor productivity in this sector to have exerted much influence on the growth rate of the overall economy. In any event, there appears to have been very little increase in non-agricultural labor productivity prior to 1800. As we noted earlier a series of real wages for the urban unskilled in Philadelphia experienced significant short-run fluctuations but showed little long-run trend. Evidence on the wages of urban professionals and skilled craft workers is more limited, but Peter Lindert and Jeffrey Williamson (2011, p. 26) find that both the share of these more skilled workers and their relative pay declined in the years between the American Revolution and 1800. Similarly, Billy Smith's (1981, pp. 195, 199) estimates of the real wages of Philadelphia tailors and cordwainers - two of the most numerous groups of urban craft 
workers-from 1762 through 1800, reveal that their earnings declined relative to the urban unskilled.

Our index of nonagricultural output per worker is based on data for urban unskilled workers. We combined the evidence on wages for Philadelphia laborers from Nash (1979) for 1727 to 1775 with that from Smith (1981) for 1751 to 1800 , and then deflated these by an estimate of the cost of living to arrive at an estimate of real wages. We used five-year averages to construct our index of real urban wages. ${ }^{34}$ Comparison with our estimates of agricultural labor productivity show that non-agricultural labor output per worker grew more slowly between 1720 and 1770 and 1720 to 1800 . After 1770, however, nonagricultural output per worker fared better, having increased at nearly the same rate as agricultural labor productivity from 1770 to 1800, and growing much faster from 1791 to $1800 .^{35}$

\section{Economic Growth in the Mid Atlantic Region: The Baseline Conjectures}

We can now turn to the result of interest, the growth of real GDP per capita. Our baseline estimates of real GDP per capita at benchmark years from 1720 to 1800 are shown in Table 4. GDP per capita advanced at an average of 0.13 percent per year over the colonial period and 0.07 percent over the period 1720 to 1800 . Incomes rose rapidly in the 1750 s ( 0.7 percent per year) and fell nearly as quickly in the 1760 s. While we are not able to construct estimates for 1780 , the figure for 1790 indicates there was a pronounced decline in GDP per capita between 1770

\footnotetext{
${ }^{34}$ We estimated the index for 1720 by assuming it had changed at the same rate from 1720 to 1725 as it had from 1725 to 1730 .

${ }^{35}$ The absence of progress in non-agricultural labor productivity appears to be consistent with most of the recent research on British wages during the early stages of the Industrial Revolution, which find that real wages did not begin to increase until after 1800. See especially, Clark (2005) and Allen (2007).
} 
and 1790, which Lindert and Williamson label the Great Reversal, and which presumably reflected the effects of the Revolution and the disruption to trading patterns caused by American independence. The 1790 s, however, witnessed a strong recovery: GDP per capita rose at 1.98 percent per year and made up almost all the gains that had been lost in the 20 years preceding 1790.

A major contributor to the fluctuations in per capita income was the volatility of labor productivity in the non-agricultural sector. As Table 4 reveals, our index of non-agricultural labor productivity (derived from the urban real wage series) rose considerably in the $1750 \mathrm{~s}$ contributing to the rise in per capita income in that decade. Similarly the drop in urban earnings between 1770 and 1790 was a major contributor to the drop in income after the Revolution. In contrast, although agricultural exports were also quite volatile, total output per worker in the agricultural sector was relatively stable because exports made up such a small part of total output. In the 1790 s the decline in the labor force participation rate pulled down real GDP per capita by a small amount, but this was offset by the positive effect emanating from a small shift in the sectoral distribution of the labor force into the more productive nonagricultural industries. In terms of our estimating series the post-1790 upsurge in GDP per capita is attributable primarily to increased output per worker: output per worker in agriculture rose at 1.4 percent per year between 1791 and 1800 (due primarily to increased exports), while non-agricultural output per worker increased by 3.4 percent per year. To some extent these increases represent recovery from the distressed conditions that had prevailed during the Revolution and the period of Confederation. For nonagriculture, the increased output per worker reflects as well the upsurge in the export trade and, perhaps especially, the re-export trade that the U.S. handled as a neutral country during war in Europe (See North 1961, chap V). 
We have also constructed a terms of trade index for the region, and used it to estimate adjusted values of GDP per capita. The terms of trade improved considerably for the region over the course of the eighteenth century, having risen on average at an annual rate of 1.1 percent per year from 1720 to 1770 and at 0.96 percent from 1720 to 1800 . As a consequence, the purchasing power of the real exports per capita rose at 1.49 percent per year in the period 1720 70 and 1.15 percent in the longer period $1720-1800$, much faster in both instances than the growth of real exports per capita. Despite the improvement in the relative price of regional exports, this adjustment had little impact on the growth of GDP per capita because exports were such a relatively small portion of the economy. GDP per capita adjusted for changes in the terms of trade rose at 0.16 percent per year instead of 0.13 percent between 1720 and 1770 , and at 0.1 percent instead of 0.07 percent between 1720 and 1800 . Because this adjustment has little impact on economic growth, the discussion below is based on the unadjusted series.

\section{Sensitivity Analysis}

The baseline figures reported in Table 4 rest on several assumptions that reflect our judgment as to the most likely trends in three variables underlying the calculation of real GDP per capita: the rate of growth of the value of the diet, the rate at which the rural agricultural participation rate declined, and the trend in nonagricultural output per worker, which we have assumed equaled that for real wages of nonagricultural workers in Philadelphia. Here we discuss altering each of these assumption and show the impact of such changes in Table 5.

As discussed above, the trend in the value of the diet was taken as the midpoint of what we argued were plausible lower and upper bounds on the growth in the diet, specifically 0.0 and 0.2 percent per year. Accordingly, we have calculated the growth of GDP per capita using those 
lower and upper bound growth rates. If these were the only changes in our calculation, the consequences are that the rate of growth of real GDP per capita would have been approximately 0.04 percentage points slower or faster over each time period. ${ }^{36}$

Our baseline estimates also rested on the assumption that the rural agricultural participation rate declined at the rate of 0.07 percent per year. ${ }^{37}$ It is possible that the rate did not decline at all. Our reading of the literature on the extent to which colonial farmers engaged in production for the market offers no suggestions that farm households were withdrawing their labor from agricultural activities. ${ }^{38}$ On the other hand, it is possible the decline was faster than 0.07 percent per year. In the nineteenth century, the rural agricultural participation rate declined more rapidly, as one would expect given the higher levels of income and faster rates of increase in income. In the Mid Atlantic region, the rate for those aged ten and over declined at 0.13 percent per year between 1800 and 1840, nearly twice the rate we have calculated for Chester county.

If the rate of decline in the rural agricultural participation rate were slower than our baseline assumption there would have been less of a shift in the industrial composition of the labor force towards the more productive nonagricultural sector which would reduce the growth

${ }^{36}$ If we allowed the diet to rise at 0.37 percent per year, the rate implied by assuming that the colonist's diet in 1730 equaled that prescribed by the Rules for Georgia, GDP per capita would have risen at 0.22 percent per year over the period 1720 to 1770 . But this rate of growth implies that the diet in 1720 would have been equal to the 1800 value of a slave's diet $(\$ 23.50)$.

37 Ball and Walton (1976, p. 109-113, Table 3) appear to have assumed there was no decline in the rural agricultural participation rates, except for children, in their index of labor inputs per farm for Chester county from 1714-31 to 1775-90. The rate of 0.07 percent that we use is a weighted average of the decline in the child participation rate and constancy in the rate for adults implicit in their estimates.

38 See Rothenberg (1992); Henretta (1978); and Kulikoff (1979). Some household members may have left agriculture to seek work in nearby cities, but that effect is captured in our conjectures because the agricultural share of the labor force changes with urbanization. 
of output per worker for the entire labor force, and the agricultural labor force would have increased faster which would reduce the rate of growth of output per worker in agriculture. If, on the other hand, the rate of decline were faster, the rates of growth of output per worker in agriculture and in total for the region would have risen faster than in the baseline case. As can be seen in Table 5 the differences are of the same order of magnitude as those found when we altered the rate of growth of the diet. If we assumed there was no decline in the rural agricultural participation rate, GDP per capita would have grown more slowly by 0.08 percent per year; if we doubled the rate of decline, then GDP per capita would have increased faster by 0.08 percent per year.

If we alter the assumption about changes in both of these variables simultaneously, the changes in real GDP per capita are altered that much more. When both variables are allowed to change more slowly, real GDP per capita would have grown at 0.12 percent less per year; if both variables had increased faster, then real GDP per capita would have increased faster by another 0.12 percent per year. In the latter case, economic growth during the colonial period would have been about 0.26 percent per year, and somewhat slower ( 0.19 percent per year) over the longer 1720 to 1800 period. The plausibility of these rates of growth, however, is questionable for two reasons. First this result implies that the value of the colonist's diet in 1720 was equal that consumed by a slave in 1800 . It seems dubious that migration into the region would have been as fast as it was if the biggest component of the average standard of living was not much better than that of a slave. Second, the results imply that agricultural output per worker increased on average over a period of 80 years at a rate in excess of that found for the first half of the 
nineteenth century $\left(0.25\right.$ percent per year). ${ }^{39}$ It seems very unlikely that small-scale farmers in the $18^{\text {th }}$ century could have made as much or more progress than their nineteenth-century counterparts at a time when there were fewer technical advances, and little means--such as farm periodicals that arose in the $19^{\text {th }}$ century--of diffusing knowledge about such advances throughout the region.

The third assumption of note, that the rate of change in non-agricultural output per worker could be approximated by changes in real wages of workers in Philadelphia, resulted in very little increase in nonagricultural output per worker over the colonial period. Output per worker in nonagriculture rose quite rapidly from 1720 to 1740 , then declined sharply in the 1740 s, rose again in the following decade and then fell once more in the 1760 s. Overall there was virtually no change (0.02 percent per year) over the colonial period. Nonagricultural output per worker fell between 1770 and 1790, but then rose sharply during the 1790s with the result that the 1800 value was about 10 percent above that in 1720 . Over the whole period 1720 to 1800 nonagricultural output per worker rose at 0.12 percent per year, half the rate of growth we estimated for agriculture. As a result, the relative productivity of non-agricultural to agricultural labor declined slightly at 0.17 percent per year from $1720-70$ and 0.13 from 1720 to 1800 , or put another way the ratio of nonagricultural output per worker to that for agricultural (k) fell from 3.1 in 1720 to 2.8 in 1770 and 1800 . If instead of relying on the direct evidence about real wages we made an alternative assumption that the value of $\mathrm{k}$ had remained constant, as had been assumed by David and Weiss in their conjectures for portions of the early nineteenth century, the

39 The rate of growth was 0.25 percent per year from 1800 to 1850 , slightly faster for the period 1800 to 1840 (0.34 percent per year). Weiss (1994, Table 1.4) and underlying worksheets. 
rate of growth of GDP per capita would have been faster by 0.08 percent per year from $1720-70$ and 0.06 from 1720 to 1800 .

In summary, reasonable changes in the three key underlying series would change the growth of GDP per capita by fairly small amounts. However, in none of the alternatives we have considered did the annual rate of growth rise to 0.3 percent per year. Nevertheless, the Mid Atlantic region experienced positive long-term growth. In our best estimate the colonial economy advanced on a per capita basis at 0.13 percent per year, with some sharper advances having occurred in the 1740 s and 1750 s. The economy took a big hit during the Revolution and the Period of Confederation, but recovered smartly after 1791. Nevertheless, the turmoil of the 1770-90 period brought down the average rate of growth for the period 1720 to 1800 to only 0.07 percent per year.

Our series shows a smoother time path than likely occurred because we are unable to measure most of the short-run fluctuations in agricultural production and shelter services. Lacking direct evidence we were obliged to assume that changes in several of the largest components of GDP were based on linear trends in underlying components. Food production, for example, was based on the assumption that the value of the diet, and thus food consumption, increased at a constant rate over time. Only for agricultural exports could we measure year-toyear fluctuations. And, the value of shelter services was based on a constant rate of the annual flow of rental services being produced by the stock of dwellings. Because of these sorts of assumptions, there is certainly less variation in our GDP per capita series than actually took place. In our series, deviations of GDP per capita from the long-term trend originated for the most part from fluctuations in the value of exports, and changing urban labor market conditions. Although the export series reveals substantial fluctuations from year to year, we do not think 
those variations capture accurately or completely the variation in GDP or GDP per capita. ${ }^{40}$

Even though our series is undoubtedly too stable, it still suggests that short-run fluctuations in economic activity were relatively pronounced for the region the economy of the Mid Atlantic region.

\section{Interpretation}

What do our estimates of economic growth for the Mid-Atlantic have to say about the region's economic performance? First, these estimates allow us to put this region's performance in perspective. The region turned in a better performance than was found for the colonies and states of the Lower South, the only other region for which we have made comparable estimates. ${ }^{41}$ For the Lower South, we estimated that real GDP per capita declined slightly - by 0.03 percent per year from 1720 to 1770 and 0.02 percent per year from 1720 to $1800 .{ }^{42}$ There is little doubt that the Middle Colonies experienced noticeably faster economic growth than the Lower South.

40 Some fluctuation in exports, agricultural output, and thus the economy as a whole, reflected variations in rainfall. The Palmer Drought Severity Index, which provides annual measures of the fluctuation in net moisture available to plants and trees, suggests the region experienced considerable climatic variation and likely suffered through a number of poor crop years as well as an equal number of bountiful years. Changes in moisture may also have influenced the trend in output, although the effect would appear to have been small. See the appendix to this paper for more detailed discussion.

${ }^{41}$ Per capita GDP increased in the Mid Atlantic at roughly the same rates as Mancall and Weiss found for all the colonies together (1999).

42 Mancall, Rosenbloom, and Weiss (2003). The poor performance of the Lower South reflects in part the decline in exports per capita, which fell at 0.04 percent per year from 1720 to 1770 and 0.6 percent from 1720 to 1800 . Another important source of the decline in GDP per capita was the changing composition of the region's population, namely a continual increase in the share of the population under the age of 10 and an increase in the free share of the population. These shifts kept the labor force participation rate from rising for most of the period and eventually pushing it down, especially after 1770 . If nothing else had changed, this phenomenon alone would have reduced GDP per capita by 0.04 percent per year between 1720 and 1770 and by 0.27 percent per year between 1720 and 1800 . 
Second, our estimates imply that the prevailing wisdom about the rate of growth in North America before 1800 needs to be reconsidered. Our baseline estimates are well below the estimates of the region's growth suggested by Egnal (1998) and McCusker (2006). ${ }^{43}$ Although the upper bound of our estimates is only slightly below the lower rate of growth of 0.3 percent per year that McCusker assumed for the colonies as a whole, it is well below the higher rate of 0.6 percent per year. Moreover, in view of what the conjectural estimating equation implies about the sources of growth it is unlikely that the Mid Atlantic region could have achieved a growth rate in the range advocated by McCusker for the colonies without an even more rapid, and more implausible, growth in agricultural labor productivity than we have assumed. ${ }^{44}$ In combination with our earlier estimates for the Lower South, the estimates reported here suggest that the plausible range of rates of growth for the colonies as a whole needs to be revised downward. $^{45}$

Third, the relative performance of the colonies in the Mid Atlantic regions and the Lower South also brings into question the importance of exports as an engine of growth in colonial America. In neither region did exports comprise a substantial portion of the economy, falling

\footnotetext{
${ }^{43}$ The rate of growth we estimate for the Middle colonies from 1720 to 1770 is well below the rate of 0.6 percent that Egnal estimated for the Northern colonies for the period 1713-75. It is possible that these two disparate rates are consistent with each other, but given the 0.13 rate of growth we estimate for the Middle colonies it would require that New England's rate of growth be quite high - roughly 1.0 percent per year - in order to bring up the Northern region's weighted average to 0.6 percent. More notably, our estimated rate of growth is very far below the 1.6 percent figure that McCusker estimated for Pennsylvania for the period 1720 to 1774 . This would seem to indicate that the behavior of exports to England, which is the evidence on which he based his estimate, is not a good measure of economic growth more generally

${ }^{44}$ More rapid growth in agricultural labor productivity would imply growth rates greater than recorded in the early nineteenth century, and would also mean that food consumption at the beginning of the period was lower than seems plausible.

${ }^{45}$ Given the population shares in the subregions, New England and the Chesapeake would had to have grown between 0.8 and 1.0 per cent per year.
} 
well short of the 25 to 30 percent share that McCusker (1999) thought it accounted for. In the Middle Colonies exports made up roughly 7 percent of GDP, and the per capita value grew around 0.36 per year during the colonial period, somewhat faster than GDP per capita. ${ }^{46}$ In the Lower South, exports figured more prominently, but still did not exceed 14 percent of GDP in most years, and declined on a per capita basis at 0.04 percent per year, about the same rate as the decline in GDP per capita (Mancall, Rosenbloom and Weiss 2003).

Elsewhere we have shown in detail that the ups and downs of the economy of the Lower South were not correlated with the fluctuations in exports, and the same pattern appears in the Middle Colonies. That is, the decadal changes in exports per capita do not appear to be highly correlated with changes in GDP per capita. ${ }^{47}$ Perhaps more telling as regards the idea of exports as the locomotive of growth is that the Lower South, the region in which exports were supposed to have driven economic growth, fared worse in terms of growth of GDP per capita than did the Middle Colonies.

Fourth, and finally, the evidence we have presented about the series that underlie our estimated growth rates suggests that, in contrast to the early nineteenth century, a number of conditions were less favorable to advances in living standards in the eighteenth century. Unlike the early nineteenth century, when the labor force to population ratio was rising, demographic trends in the colonial era were either neutral or tended to offset rising labor productivity. While slowing natural increase and accelerating immigration after 1800 contributed to a rise in the

\footnotetext{
46 The 7 percent figure for the Middle Colonies includes both agricultural and nonagricultural commodities. Agricultural products alone amounted to about 5 percent of GDP.

${ }^{47}$ Luckily so in some instances, such as the 1730s, when exports per capita abroad and to other colonies both declined while GDP per capita rose ever so slightly at 0.03 percent per year due to growth in food production and the value of shelter per capita.
} 
Labor Force Participation Rate, in the colonial period, the LFPR held steady for the most part. It dipped in the decades immediately after 1720 , but regained its starting value by 1770 . It fell noticeably after 1770 , and for the entire period 1720 to 1800 changes in the participation rate served to reduce the growth of GDP per capita. Likewise, sectoral shifts in the composition of the economy from agriculture to nonagriculture, which were a source of aggregate growth after 1800, were of little importance. The agricultural share of the labor force rose slightly from 1720 to 1740 and then declined; the 70 percent share in 1800 was only slightly below the 72.5 percent of 1720 , so there was very little positive impact on productivity arising from a shift into the more productive nonagricultural industries. ${ }^{48}$

In the face of demographic factors, our conjectures imply that any improvement in living standards was dependent upon increased output per worker and the gradual accumulation of capital assets.. Based on our assumption of a rising level of food consumption, agricultural output per worker rose on average at 0.17 percent per year from 1720 to 1770 and 0.24 percent from 1720 to 1800 . Had the labor force participation rate remained constant and output per worker increased as we have calculated, then GDP per capita would have grown by about $\$ 13$ between 1720 and 1800. Because the participation rate fell from .31 to .27 , however, a large portion of this positive effect of rising labor productivity was offset. ${ }^{49}$ All of the decline in the participation rate took place after 1770 , so that during the colonial period, the increase in output per worker accounted for most of the increase in GDP per capita.

\footnotetext{
48 The small decline in the share of agriculture reflects the decline in the rural agricultural participation rate, not an increase in urbanization. The urban share of the region's population declined from 16.5 percent in 1720 to 9.8 percent in 1800 .

49 The decline in the participation rate reflects the changing composition of the population that occurred after 1770, especially the decline in the adult male share of the population because adult males had a much higher participation rate than adult females.
} 
Most of the remaining increase in GDP per capita was generated by the growth of the housing stock and the resulting flow of shelter services it produced. In other words, capital accumulation, at least in this one sector, was an important force contributing to rising incomes. If nothing else had held the economy in check, the rise in the stock of housing would have pushed up GDP per capita by more than $\$ 0.75$ during the colonial period and by another $\$ 1$ after 1770 . That alone would have generated growth in GDP per capita of 0.07 percent per year.

Taken together these observations suggest that the dynamics of aggregate growth in North America underwent a significant transition between the eighteenth and nineteenth centuries; shifting from an economy dominated by extensive growth and subject to significant short-run fluctuations, to one in which the sustained growth of living standards came to stand out as increasingly important. 


\begin{tabular}{|l|c|c|c|c|}
\hline & \multicolumn{3}{|c|}{ Table 1 } & \\
\hline & \multicolumn{3}{|c|}{ Estimates of Annual Rates of Economic Growth per Capita } \\
\hline & $\begin{array}{c}\text { Publication } \\
\text { Date }\end{array}$ & Time Period & $\begin{array}{c}\text { Geographic } \\
\text { coverage }\end{array}$ & $\begin{array}{c}\text { Rate of } \\
\text { Growth }\end{array}$ \\
\hline & & & & \\
\hline Mancall and Weiss & 1999 & $1700-1770$ & all colonies & $0.05 \%$ \\
\hline Jones & 1980 & $1700-1770$ & all colonies & $0.4 \%$ \\
\hline Egnal & 1998 & $1713-1775$ & all colonies & $0.5 \%$ \\
\hline $\begin{array}{l}\text { McCusker and } \\
\text { Menard }\end{array}$ & 1991 & $1690-1785$ & all colonies & $0.3-0.6 \%$ \\
\hline McCusker & 2000 & $1720-1774$ & all colonies & $0.6 \%$ \\
\hline Taylor & 1964 & $1700-09$ to $1770-79$ & all colonies & $1.0 \%+$ \\
\hline & & & & \\
\hline & 1979 & $1700-09$ to $1770-79$ & New England & $-0.80 \%$ \\
\hline Anderson & 1998 & $1713-1775$ & $\begin{array}{c}\text { Northern } \\
\text { colonies }\end{array}$ & $0.60 \%$ \\
\hline $\begin{array}{l}\text { Mancall, Rosenbloom } \\
\text { and Weiss }\end{array}$ & 2003 & $1720-1770$ & Lower South & $-0.03 \%$ \\
\hline Egnal & 1998 & $1713-1775$ & Lower South & $0.10 \%$ \\
\hline Main and Main & 1988 & $1650-1770$ & $\begin{array}{c}\text { So. New } \\
\text { England }\end{array}$ & $0.35 \%$ \\
\hline Kulikoff & 1979 & $1705-1776$ & Chesapeake & $0.40 \%$ \\
\hline Egnal & 1998 & $1730-1770$ & Pennsylvania & $1.60 \%$ \\
\hline Egnal & 1972 & & & $0.90 \%$ \\
\hline McCusker & & & & \\
\hline
\end{tabular}




\section{Notes and Sources to Table 1}

These authors did not all measure growth of real GDP per capita. Some specifically described it as such, some as Gross or Net National Product or National Income, while others implied that they were describing change in one of these measures of economic growth, but the specific evidence they used was some proxy measure, such as TFP or imports.

Peter Mancall and Thomas Weiss (1999, pp. 7-40) measured real GDP per capita using the conjectural method.

Marc Egnal (1998, p. 43) measured per capita imports as a first approximation, "then checked against data for long term changes in probate wealth and value of exports."

Alice Hanson Jones (1980, p. 78) used change in wealth as a proxy for GDP.

George Rogers Taylor, (1964, pp. 24, 437) examined a variety of evidence and provided an informed opinion about the rate of growth of income per capita.

John McCusker and Russell Menard (1985, pp. 52-57) estimated the rate of growth of GNP per capita based on estimates of the growth of GNP per capita for England current at the time that they wrote. The lower rate of 0.3 percent was that achieved by England, which they argue set the lower bound for the colonies; the higher rate of 0.6 percent reflected their view that because the colonies had started out far behind they likely grew faster than the mother country.

John McCusker (2000, p. 156, Table 2). In the accompanying text he revealed his preference for the higher rate of growth of 0.6 percent per year.

Terry Anderson, (1979, p. 253, Table 3 and p.255). His estimate of minus 0.8 percent per year is based on his estimate of TFP. If one used output per worker the rate of decline is only minus 0.7 percent per year.

Peter Mancall, Joshua Rosenbloom and Thomas Weiss (2003, pp. 389-424) measured real GDP per capita using the conjectural method.

Gloria L. Main and Jackson T. Main (1988, pp. 27-46) measured real wealth per capita.

Alan Kulikoff (1979, p. 277) measured real wealth per capita in Prince George's county, Maryland.

John McCusker (1972, p. 155, fn 17) used growth in exports to England as a measure of growth in NNP. 


\begin{tabular}{|c|c|c|c|c|}
\hline & \multicolumn{2}{|r|}{ Table 2} & & \\
\hline \multicolumn{5}{|c|}{ Estimates of GDP and Components in the Base Year of 1800: U.S. and Middle Atlantic Region } \\
\hline & \multicolumn{3}{|c|}{\begin{tabular}{l|l} 
(U.S. dollars, prices of 1840) \\
\end{tabular}} & \\
\hline & \multicolumn{2}{|c|}{ United States } & \multicolumn{2}{|l|}{ Mid Atlantic } \\
\hline & \multicolumn{2}{|c|}{ Non-Indian Population } & \multicolumn{2}{|c|}{ Non-Indian Population } \\
\hline & Totals & Per Capita & Totals & Per Capita \\
\hline & $\$ 000$ 's & $\underline{\$ \mathrm{~s}}$ & $\$ 000$ 's & $\underline{\$ s}$ \\
\hline Agricultural Output & 167,772 & 31.61 & 47,712 & 32.56 \\
\hline Food Production & 149,966 & 28.26 & 37,615 & 25.67 \\
\hline Food (consumption) & 159,098 & 29.98 & 45,206 & 30.85 \\
\hline less interstate food imports & - & - & 4,337 & 2.96 \\
\hline less food imports from abroad & 9,132 & 1.72 & 3,253 & 2.22 \\
\hline Agric Exports Abroad & 17,806 & 3.36 & 5,539 & 3.78 \\
\hline Agr. Exports to Other Colonies/States & - & - & 4,557 & 3.11 \\
\hline Shelter & 20,381 & 3.84 & 9,281 & 6.33 \\
\hline Non-Shelter NonAgr. Output & 163,369 & 30.78 & 57,580 & 39.29 \\
\hline \multirow[t]{2}{*}{ GDP (Narrowly Defined) } & 351,522 & 66.24 & $\$ \quad 114,573$ & 78.19 \\
\hline & \multicolumn{3}{|c|}{ 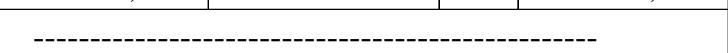 } & \\
\hline Labor Force (1,000s of workers) & 1713.2 & & 402 & \\
\hline Agricultural & 1262.2 & & 281 & \\
\hline NonAgricultural & 451.0 & & 121 & \\
\hline \multicolumn{5}{|l|}{ Output per worker } \\
\hline Agricultural & 133 & & 170 & \\
\hline NonAgricultural (EXCL Shelter) & 362 & & 476 & \\
\hline $\begin{array}{c}\text { Ratio NonAgric. To Agric. } \\
\text { Output per Worker }\end{array}$ & 2.73 & & 2.80 & \\
\hline
\end{tabular}

\section{Notes and Sources to Table 2}

Population figures for the U.S. and the Mid Atlantic region underlying the calculations are from Carter, et al., 2006, Series Aa: 2769-71, 4779-81, 4943-45, and 5407-09. The labor force figures are from Weiss (1992)

The figures for GDP and its components for the U.S. in 1800 were taken from Weiss (1992). The GDP figures for the Mid Atlantic region in 1800 were derived by extrapolating backward an estimate of the region's per capita income for 1840. The extrapolating index for per capita income was constructed as the product of indexes measuring changes in the same variables that underlie the estimates of the national figures - changes in the agricultural share of the region's labor force, changes in the region's labor force participation rate, changes in agricultural productivity - and an assumption that the ratio of non-agricultural productivity to agricultural productivity remained constant over the period at the value established for 1840. It was further assumed that agricultural productivity in the region changed at the national rate between 1800 and 1840. The region's per capita income for 1840 is based on the estimates of Easterlin. (1960, pp. 97-98, Table A-1) 
Agricultural output is the sum of Food Production, Agricultural Exports Abroad and Agricultural Exports to Other States. Food Production equals food consumption less food imports from other states and from abroad.

Per capita food consumed by free adults (those aged 10 and over) and free children (aged 0-9) in the Mid Atlantic in 1800 was assumed to equal the average of the national figures for those population groups in 1839, 1849, and 1859. The national figures were calculated from data in Gallman (1960, table, A-2) and U.S. Census Bureau (1975, series U-215 and 216). Food consumption per slave was assumed to equal 75 percent that of free whites. These per capita figures were then multiplied by the population in each group in 1800 to obtain a weighted average value for that year.

We estimated the 1800 values of agricultural imports from other states by extrapolating forward the 1768-72 benchmark figures (described in the notes to Table 3). An estimate of the region's exports to and imports from other states was derived for 1790-92 by multiplying the 1768-72 value of exports per ton cleared (for exports) and per ton entered (for imports) by reported figures for the coastal tonnage entering the ports of New York and Pennsylvania, and inflating these to obtain the value for the Middle Atlantic Region. The average per capita values of coastal exports and imports for 1790-92 were then extrapolated forward to 1802 in two parts, using figures on the stock of registered and licensed tonnage. The 1791 figure was first extrapolated to 1794 based on the gross tonnage engaged in coastal and internal trade. The 1794 figure was then extrapolated forward based on the enrolled tonnage and the tonnage of licensed vessels employed in the coasting trade in the states of the Middle Atlantic. In both cases the extrapolator was a three-year average of tonnage per capita. The tonnage data are from Carter et al, 2006, Series Df591 and New American State Papers, vol.4, pp. 453-55.

Food imports from abroad were estimated by calculating food imports per capita for the US., converting to 1840 prices, then multiplying by the 1768-72 ratio of the Mid Atlantic's per capita food imports to those for the US. We calculated food imports in 1800 as a share of total merchandise imports (Carter, et al, 2006, Series Ee 368) less re-exports (Mancall, Rosenbloom and Weiss, 2008, Appendix Table 8). The 1768-72 ratio is from, Shepherd (1970, Tables 1 and 2).

For exports see Mancall, Rosenbloom and Weiss (forthcoming), the Appendix to that paper, as well as the Appendix to this paper.

For the free population, the value of shelter services equals 10 percent of the value of the stock of dwellings in 1798 adjusted for omitted values (Weiss, 1992, Table 1.2; Pitkin, 1967; Soltow, 1989; and Soltow and Land, 1980). The flow was revalued in prices of 1840 by using the deflator for the gross rental value of farm dwellings estimated by Towne and Rasmussen (1960) to obtain a per capita figure for free persons of $\$ 6.34$. We assumed that the average value of a slave dwelling in each state equaled the value of those dwellings omitted from the housing survey. That value was calculated for each state as the product of the national ratio of the value of omitted dwellings to reported dwellings times the value of the reported dwellings in each state. This gave a dwelling value per slave of $\$ 7.18$ in 1800 prices. Using a service flow of 10 percent and converting to 1840 prices we obtain the annual value of shelter of $\$ 0.97$ per slave.

Nonagricultural output is the difference between the total GDP and the estimates of Agricultural Output and the value of Shelter. This residual encompasses all nonagricultural output, except shelter. Thus it includes the output of fishing, forestry, manufacturing, mining, construction, final services flowing to consumers, the value of government services as well as investment spending. 
Table 3

Per Capita Values of Agricultural Output for the Colonies and States of the Mid Atlantic Region (US Dollars, prices of 1840)

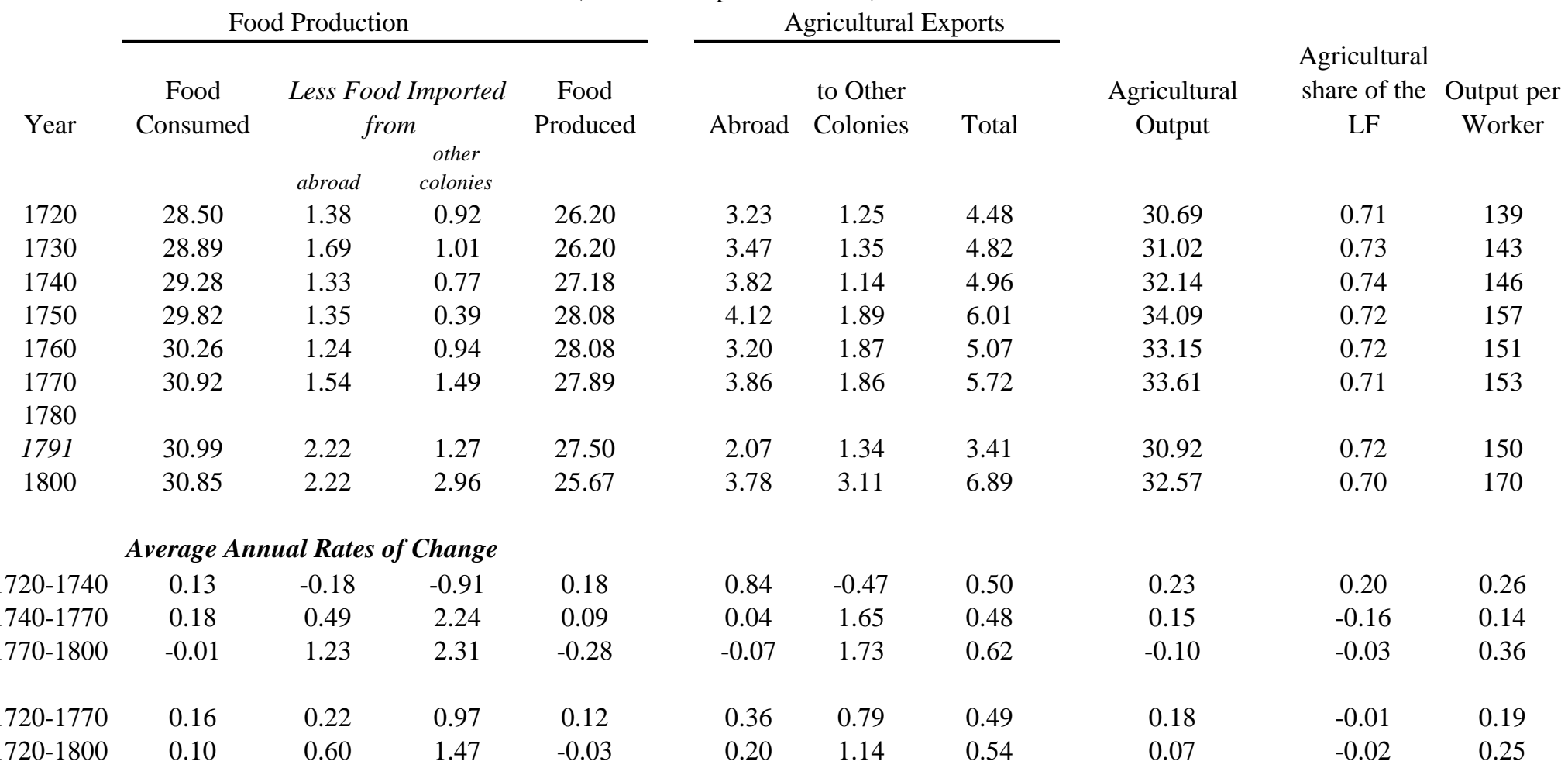

\section{Notes and Sources to Table 3}

The value of food consumed per capita is a weighted average of the value consumed by the colonists and that consumed by the slaves, and the average for the colonists is a weighted average of that consumed by an adult and that consumed by a child, where the weights are their respective shares of the population. Children are those under the age of 10 . 
We assumed that the per capita consumption figure for free adult colonists increased at an average annual rate of 0.1 percent per year between 1720 and 1800. The per capita figure for slaves was assumed to equal 75 percent that of a colonist in every year.

The estimate of food imports from and agricultural exports to other colonies for 1768-72 comes from Shepherd and Williamson (1992, p. 798, Table 2). We calculated the implicit quantities of most food items, revalued them using dollar prices of 1840 , then inflated their sum by dividing it by the share of these food items in the total value of food (in pound sterling) in the original data. We calculated average value per ton of agricultural exports to and imports from other colonies by dividing the base year values by the average tonnage clearing and entering in the years 1768-1772, and extrapolated these values to other years using statistics on tonnage entering and clearing.

Food imports into the Middle Colonies from Southern Europe, the Wine Islands, and the West Indies for 1768-72 are from Shepherd (1970, Tables 1 and 2). Imports of food from Great Britain were calculated as 3 percent of all imports from that source. The total import figure was taken from Carter, et al (2006, Series Eg452-455). We calculated average value per ton of agricultural imports for three points of origin (Europe, Britain and the West Indies) by dividing the base year values by the average tonnage entering from these other destinations in the years 1768-1772. We multiplied these values per ton by tonnage entering New York and Philadelphia from these three points to estimate the value of food imported from foreign countries. The tonnage data are from Carter (2006) and Lydon (1967).

Agricultural exports abroad include only those exports produced domestically. The benchmark figure for agricultural exports from the Middle Colonies to all countries in 1770 is from Shepherd and Walton (1972, pp. 210-227) revalued in 1840 prices of each. We then extrapolated that benchmark figure forward to 1800 and extrapolated it backward to 1720 based on tonnage clearing Philadelphia and New York. See Mancall, Rosenbloom and Weiss, (forthcoming).

Total agricultural output equals the sum of food produced and total agricultural exports.

The agricultural labor force is the sum of estimates for the white and black workers residing in rural areas, plus an estimate of the small numbers of the population in farming that were residing in cities. For each of the two rural population groups, the agricultural labor force is the product of the rural population in that group times a rural agricultural participation rate. The 1800 rural agricultural estimating ratios were taken from Weiss's earlier estimates of the U.S. labor force. We assumed those ratios declined over the period 1700 to 1800 at 0.07 percent per year, a rate derived from the labor force evidence for Chester county, Pennsylvania presented by Ball and Walton ((1976, Table 3 p. 109-113). Their indexes of labor inputs per farm for Chester county from 1714-31 to 1775-90 appear to have assumed there was no decline in the rural agricultural participation rates, except for children. The rate of 0.07 percent is a weighted average of the decline in the child participation rate and constancy in the rate for adults implicit in their estimates. That rate of decline is roughly half the rate at which the free labor force aged 10 and over declined in the period 1800 to 1840 ( 0.131 percent per year). The urban farm labor force was assumed to equal one percent of the urban population aged 10 and over, the percentage used by Weiss in his estimates for the nineteenth century. Evidence for Philadelphia in 1774 and 1780-83 ( Price, 1974) provides some confirmation for this percentage. 


\begin{tabular}{|c|c|c|c|c|c|c|c|c|}
\hline & & & & Table 4 & & & & \multirow[b]{3}{*}{$\begin{array}{c}\text { GDP per } \\
\text { Capita }\end{array}$} \\
\hline & \multicolumn{7}{|c|}{ Conjectural Estimation of GDP per Capita for the Mid Atlantic Region, 1720-1800 } & \\
\hline & $\begin{array}{c}\text { LF Part. } \\
\text { Rate }\end{array}$ & $\begin{array}{l}\text { Agric. } \\
\text { Output per } \\
\text { worker }\end{array}$ & \begin{tabular}{|c|} 
NonAgric. \\
Output (excl \\
shleter) per \\
Worker \\
\end{tabular} & $\begin{array}{l}\text { Agric. } \\
\text { Share of } \\
\text { the LF }\end{array}$ & $\begin{array}{c}\text { NonAgric } \\
\text { Share of } \\
\text { the LF }\end{array}$ & $\begin{array}{l}\text { Extrapolated } \\
\text { Value of Non- } \\
\text { shelter GDP } \\
\text { per capita }\end{array}$ & $\begin{array}{l}\text { Value of } \\
\text { Shelter }\end{array}$ & \\
\hline 1720 & 0.31 & 139.06 & 430.69 & 0.71 & 0.29 & 69.22 & 4.59 & 73.81 \\
\hline 1730 & 0.30 & 143.25 & 495.71 & 0.73 & 0.27 & 71.21 & 4.44 & 75.65 \\
\hline 1740 & 0.30 & 146.42 & 510.71 & 0.74 & 0.26 & 71.44 & 4.63 & 76.07 \\
\hline 1750 & 0.30 & 156.93 & 458.98 & 0.72 & 0.28 & 72.61 & 4.83 & 77.44 \\
\hline 1760 & 0.30 & 150.88 & 530.19 & 0.72 & 0.28 & 78.24 & 5.07 & 83.31 \\
\hline 1770 & 0.31 & 152.71 & 434.32 & 0.71 & 0.29 & 73.35 & 5.36 & 78.70 \\
\hline \multicolumn{9}{|l|}{1780} \\
\hline 1791 & 0.29 & 149.72 & 351.21 & 0.72 & 0.28 & 59.49 & 5.97 & 65.46 \\
\hline 1800 & 0.27 & 169.86 & 475.50 & 0.70 & 0.30 & 71.76 & 6.34 & 78.10 \\
\hline \multicolumn{9}{|c|}{ Average Annual Rates of Change } \\
\hline $1720-1740$ & -0.23 & 0.26 & 0.86 & 0.20 & -0.53 & 0.16 & 0.04 & 0.15 \\
\hline $1740-1770$ & 0.17 & 0.14 & -0.54 & -0.16 & 0.41 & 0.09 & 0.49 & 0.11 \\
\hline $1770-1800$ & -0.43 & 0.36 & 0.30 & -0.03 & 0.08 & -0.07 & 0.56 & -0.03 \\
\hline $1720-1770$ & 0.01 & 0.19 & 0.02 & -0.01 & 0.04 & 0.12 & 0.31 & 0.128 \\
\hline $1720-1800$ & -0.15 & 0.25 & 0.12 & -0.02 & 0.05 & 0.05 & 0.40 & 0.071 \\
\hline $1720-30$ & -0.41 & 0.30 & 1.42 & 0.22 & -0.57 & 0.28 & -0.33 & 0.25 \\
\hline $1730-40$ & -0.04 & 0.22 & 0.30 & 0.18 & -0.48 & 0.03 & 0.42 & 0.06 \\
\hline $1740-50$ & 0.16 & 0.70 & -1.06 & -0.26 & 0.71 & 0.16 & 0.42 & 0.18 \\
\hline $1750-60$ & 0.12 & -0.39 & 1.45 & -0.01 & 0.01 & 0.75 & 0.50 & 0.73 \\
\hline $1760-70$ & 0.22 & 0.12 & -1.97 & -0.20 & 0.51 & -0.64 & 0.54 & -0.57 \\
\hline $1791-1800$ & -0.54 & 1.41 & 3.42 & -0.28 & 0.69 & 2.11 & 0.67 & 1.98 \\
\hline
\end{tabular}




\section{Notes and Sources to Table 4}

The Labor Force Participation Rate is a weighted average of that for free males, free females, and slaves aged 10 and over. The participation rates for each of the population groups are those for 1800 (Weiss, 1992). Agricultural output per worker and share of the labor force are from Table 3.

The input values (cols. 1-5) are used to calculate the extrapolated value of GDP per capita. The independent estimate of the value of shelter is then added to the extrapolated value to obtain the full measure of GDP, narrowly defined (i.e. excluding home manufactures and farm improvements).

The agricultural output per worker data are from Table 3. The nonagricultural output per worker series is based on wages of Philadelphia laborers taken from Nash (1979) for 1727 to 1775 and Smith (1981) for 1751to1800. We used five year averages to construct an index which was used to extrapolate the 1800 base year value of nonagricultural output per worker. We estimated the index for 1720 by assuming the index had changed at the same rate from 1720 to 1725 as it had from 1725 to 1730 .

The per capita value of shelter in 1800 is a weighted average of that for the free population $(\$ 6.49)$ and for slaves (\$0.97). We used an index of change in the stock of dwellings to extrapolate the 1800 figures backward to 1700. We based the index on Jones's (1980, p.78) estimate of the rate of growth of wealth per capita between 1700-25, 1725-50, and 1750-74, and Gallman's (1992, p. 95) estimate of the rate of growth of the real value of structures between 1774 and 1799.

It is worth noting that the 1800 base year values in our conjectures reflect the degree of market orientation in that year, a degree which is then implicit in our estimates for earlier years. To the extent that the marketed share of output increased over the period from 1720 to 1800 our estimated rates of growth understate the increase of market-based GDP. It is possible that the higher rates of growth estimated by others have implicitly taken this increased commercialization into account, and thus the difference between our estimate of growth and theirs would be a measure of the rate at which market orientation had increased. (Grubb, 2004, pp. 351-56). 


\begin{tabular}{|c|c|c|c|c|c|c|c|c|c|}
\hline & & & & Table 5 & & & & & \\
\hline & & & \multicolumn{5}{|c|}{ Sensitivity Analysis of Several Key Assumptions } & & \\
\hline & & & & & & & & & \\
\hline & \multicolumn{3}{|c|}{$\begin{array}{c}\text { Assumed Rate of Change in the Value } \\
\text { of the Diet }\end{array}$} & \multicolumn{3}{|c|}{$\begin{array}{c}\text { Assumed Rate of Change in the Rural } \\
\text { Agricultural Participation Rate }\end{array}$} & \multicolumn{3}{|c|}{$\begin{array}{l}\text { Assumed Both variables Changed slower or } \\
\text { faster than the baseline case }\end{array}$} \\
\hline & Baseline Case & slower & faster & Baseline Case & slower & faster & Baseline Case & slower & faster \\
\hline & 0.1 & 0.00 & 0.20 & 0.07 & 0.00 & 0.13 & $\begin{array}{c}\text { Diet }=0.1 \\
\text { AgLFPR }=0.07\end{array}$ & $\begin{array}{c}\text { Diet }=0.0 \\
\text { AgLFPR }=0.0\end{array}$ & $\begin{array}{c}\text { Diet }=0.2 \\
\text { AgLFPR }=0.13\end{array}$ \\
\hline & vara & $\operatorname{varb}$ & $\operatorname{varc}$ & vara & vard & vare & var $a$ & $\operatorname{varf}$ & var $g$ \\
\hline Real GDP per capita & & & & & & & & & \\
\hline 1720 & 74 & 76 & 72 & 74 & 79 & 69 & 74 & 82 & 67 \\
\hline 1770 & 79 & 80 & 78 & 79 & 81 & 77 & 79 & 82 & 76 \\
\hline 1800 & 78 & 78 & 78 & 78 & 78 & 78 & 78 & 78 & 78 \\
\hline \multicolumn{10}{|c|}{ Implied Rates of Growth of Real GDP per capita } \\
\hline $1720-70$ & $\begin{array}{r}0.128 \\
\end{array}$ & 0.085 & 0.165 & 0.128 & 0.043 & 0.214 & 0.128 & 0.007 & 0.255 \\
\hline $1720-1800$ & 0.071 & 0.031 & 0.108 & 0.071 & -0.014 & 0.152 & 0.071 & -0.051 & 0.192 \\
\hline & & & & & & & & & \\
\hline \multicolumn{10}{|c|}{ Implied Rates of Growth of Agricultural Output per Worker } \\
\hline $1720-70$ & \begin{tabular}{|r|}
0.190 \\
\end{tabular} & 0.090 & 0.280 & 0.190 & 0.120 & 0.250 & 0.190 & 0.020 & 0.340 \\
\hline $1720-1800$ & 0.250 & 0.160 & 0.340 & 0.250 & 0.180 & 0.310 & 0.250 & 0.090 & 0.400 \\
\hline \multicolumn{10}{|c|}{ Value of the Diet (slave diet in $1800=\$ 23.45$ ) } \\
\hline in 1720 & $\begin{array}{ll}\$ & 29.27\end{array}$ & $\$ \quad 31.71$ & $\$ 27.02$ & 29.27 & 31.71 & 27.02 & 29.27 & 31.71 & 27.02 \\
\hline $\begin{array}{l}\text { relative to } 1800 \\
\text { slave diet }\end{array}$ & $125 \%$ & $135 \%$ & $115 \%$ & $125 \%$ & $135 \%$ & $115 \%$ & $125 \%$ & $135 \%$ & $115 \%$ \\
\hline
\end{tabular}

\section{Notes to Table 5}

See the text for a discussion of the different variants.

For purposes of comparison, the slave diet in 1800 equaled $\$ 23.45$; the rate of growth of agricultural output per worker from 1800 to 1850 was 0.25 percent per vear. 


\section{SOURCES}

Allen, Robert C. 2007. "Pessimism Preserved: Real Wages in the British Industrial Revolution." University of Oxford, Department of Economics working paper no. 314.

Allen, Robert C., Tommy E. Murphy and Eric B. Schneider. 2011. "The Colonial Origins of the Divergence of the Americas: A Labour Market Approach." University of Oxford, Department of Economics discussion paper no. 559.

Anderson, Terry. 1979. "Economic Growth in Colonial New England: 'Statistical Renaissance,"” The Journal of Economic History, 39, 243-57.

Archives of the State of New Jersey, First Series, Vol. 7, "Administration of Governor Belcher," pp. 101-401, Newark, NJ.

Ball, Duane and Gary Walton. 1976. "Agricultural Productivity change in eighteenth century Pennsylvania, The Journal of Economic History 36, 102-17.

Berlin, Ira. 1980. "Time, Space, and the Evolution of Afro-American Society on Mainland British North America," American Historical Review 85 (1980), 44-78.

Bolt, Jutta and Jan Luiten van Zanden. 2013. "The First Update of the Maddison Project: ReEstimating Growth Before 1820." Maddison-Project Working Paper WP-4. University of Groningen (January).

Broadberry, Stephen et al. 2013. "When did Britain industrialise? The sectoral distribution of te labour force and labour productivity in Britain, 1381-1851." Explorations in Economic History 50, 16-27.

Bushman, Claudia L., Harold B. Hancock, and Elizabeth Moyne Homsey, eds. 1986. Proceedings of the House of Assembly of the Delaware State, 1776-1781, Newark: University of Delaware Press.

Candler, Allen D. 1904-16. The Colonial Records of the State of Georgia. Compilations of transcripts of records in the Public Record Office begun by Allen D. Candler and completed by William J. Northen and Lucian Lamar Knight.

Carter, Susan, et al. 2006. Historical Statistics of the United States, New York: Cambridge University Press.

Clark, Gregory. 2005. "The Condition of the Working-Class in England, 1209-2004." Univeristy of California, Davis, Department of Economics working paper \#05-39.

Clark, Gregory. 2010. “The Macroeconomics Aggregates for England, 1209 to 2008," Research in Economic History.

Clark, Gregory. 2013. "1381 and the Malthus delusion." Explorations in Economic History 50, 4-15.

Cole, Arthur Harrison.1938. Wholesale Commodity Prices in the United States, 1700-1861. Cambridge: Harvard University Press.

Colonial Records of Pennsylvania, Vol. 13, Sept., 1781, Dec., 1781; Mar., 1782; April 1782, Sept. 1782, and Nov. 1782 
David, Paul. 1967. "The Growth of Real Product in the United States before 1840: New Evidence, Controlled Conjectures." Journal of Economic History 27: 151-97

Documents from the Continental congress, June 10, 1777 (on-line at hdl.loc.gov/loc.rbc/bdsdcc.03301)

Egnal, Marc. 1998. New World Economies. New York: Oxford University Press,

Gallman, Robert. 1971. "The Statistical Approach: Fundamental Concepts Applied to History," in G.R.Taylor and L.F.Ellsworth, eds. Approaches to American Economic History. Charlottesville: The University Press of Virginia.

Gallman, Robert 1992. "American Economic Growth before the Civil War." In R. Gallman and J. Wallis, American Economic Growth and Standards of Living before the Civil War. Chicago: University of Chicago Press.

Gallman, Robert. 1999. "Can We Build National Accounts for the Colonial Period," in William and Mary Quarterly.

Gallman, Robert and Thomas Weiss. 1969. "The Service Industries in the Nineteenth Century," in Victor Fuchs, ed. Production and Productivity in the Service Industries.

Goldsmith, Raymond. 1952 "The Growth of Reproducible Wealth in the United States of America from 1805 to 1950." International Association for Research in Income and Wealth. Income and Wealth Series II. Income and Wealth of the United States: Trends and Structures. Cambridge: Bowes and Bowes, 1952.

Gordon, Thomas. 1829. The History of Pennsylvania, Philadelphia.

Gottlieb, Manuel. 1964. Estimates of Residential Building, 1840-1939, NBER Technical Paper no. 17.

Greenberg, Douglas. 1979. "The Middle Colonies in Recent American Historiography," William and Mary Quarterly $3^{\text {rd }}$ Ser., 36 (1979), 396-427.

Grubb, Farley. 1992. "The Long Run Trend in the Value of European immigrant Servants, 16541831: New Measurements and Interpretations," Research in Economic History, 14, 167 240.

Grubb, Farley. 2004. "The circulating medium of exchange in colonial Pennsylvania, 1729-1775: new estimates of monetary composition, performance, and economic growth," Explorations in Economic History, 41, 329-60.

Henretta, James A. 1978. "Families and Farms: Mentalite in Preindustrial America." William and Mary Quarterly, $3^{\text {rd }}$ ser., 35, 3-32.

Jones, Alice Hanson. 1980. Wealth of a Nation to Be. New York: Columbia University Press

Kahn, Charles. 1992. "A Linear Programming Solution to the Slave Diet." In Robert Fogel and Stanley Engerman, eds., Without Consent or Contract. Technical papers, vol. 3, pp. 52235. New York: W. W. Norton.

Komlos John. 2001. "On the Biological Standard of Living of Eighteenth Century Americans: Taller, Richer, Healthier." Research in Economic History, vol. 20, pp. 223-48. 
Kulikoff, Alan. 1979. "The Economic Growth of the Eighteenth-Century Chesapeake Colonies," The Journal of Economic History, 39, 275-88.

Kuznets, Simon. 1952. "Long Term Changes in the National Income of the United States of America since 1870." In Income and Wealth of the United States, Trends and Structure. International Association for Research in Income and Wealth, Income and Wealth Series II. Baltimore, Md.: The Johns Hopkins University Press.

Landon-Lane John, Hugh Rockoff and Richard H. Steckel. 2011. "Droughts, Floods and Financial Distress in the United States," Table 3b, in The Economics of Climate Change: Adaptations past and present. Gary D. Libecap and Richard H. Steckel, eds. National Bureau of Economic Research. Chicago: University of Chicago Press.

Lebergott, Stanley. 1966. "Labor Force and Employment, 1800-1960." In Dorothy Brady, ed., Output, Employment and Productivity in the United States after 1800. Studies in Income and Wealth, no. 30. New York: National Bureau of Economic Research.

Lindert, Peter H and Jeffrey G. Williamson. 2011. “American Incomes Before and After the Revolution.” NBER working paper 17211.

Leunig, Tim. 2013."Understanding the English economy 1381-1869: Editor's introduction." Explorations in Economic History. 50, 1-3.

Lydon, James. 1967. "Philadelphia’s Commercial Expansion, 1720-1739," Pennsylvania Magazine of History and Biography, 91, 401-19.

Main, Gloria L. and Jackson T. Main. 1988. "Economic Growth and the Standard of Living in Southern New England," The Journal of Economic History, 48, 27-46.

Mancall, Peter C. and Thomas Weiss. 1999. "Was Economic Growth Likely in British North America?" Journal of Economic History 59, 17-40.

Mancall, Peter, Joshua Rosenbloom and Thomas Weiss. 2003. "Conjectural Estimates of Economic Growth in the Lower South, 1720 to 1800," in History Matters:

Economic Growth Technology, and Population, ed. William Sundstrom and Tim Guinnane (Stanford: Stanford University Press, 2003), 389-424.

Mancall, Peter, Joshua Rosenbloom and Thomas Weiss. 2008. "Commodity Exports, Invisible Exports and Terms of Trade for the Middle Colonies, 1720 to 1775," NBER Working Paper No. 14334.

Mancall, Peter, Joshua Rosenbloom and Thomas Weiss. forthcoming. "Exports from the States and Colonies of the Mid Atlantic Region, 1720-1800, Research in Economic History.

McConnell, Michael. 2004. Army \& Empire, Lincoln, University of Nebraska Press.

McCusker, John. 1972. "Sources of Investment Capital in the Colonial Shipping Industry," The Journal of Economic History, 32, p. 155.

McCusker, John. 1999. "Measuring Colonial Gross Domestic Production: an Introduction," William and Mary Quarterly, vol. 56, Jan. 1999, p. 3-8. 
McCusker, John. 2000. "Estimating Early American Gross Domestic Product, Historical Methods, vol. 33, 2000, p. 156, Table 2 and accompanying text. Here he revealed his preference for the higher rate of growth of 0.6 percent per year.

McCusker, John. 2006. "Colonial Statistics," in Susan Carter, et al, (2006). Historical Statistics of the United States: Earliest Times to the Present (Cambridge University Press), vol. 5,

McCusker, John J. and Russell R. Menard (1984). The Economy of British America, 16071789: Needs and Opportunities for Study. Institute of Early American History and Culture. Chapel Hill and London: University of North Carolina Press.

Menard, Russell. 1976. "Comment on Paper by Ball and Walton," The Journal of Economic History 36, 118-25.

Nash, Gary B. 1979. The Urban Crucible: Social Change, Political Consciousness, and the Origins of the American Revolution. Cambridge, MA: Harvard University Press.

New American State Papers, Commerce and Navigation, vol.4

North, Douglass. 1961. The Economic Growth of the United States, 1790 to 1860, Englewood Cliffs, NJ: Prentice-Hall.

Palmer,Wayne C. "Meteorological Drought.” Research Paper No. 45. U.S. Weather Bureau, Washington, DC.

Parker, Peter J. 1975. "Rich and Poor in Philadelphia," Pennsylvania Magazine of History and Biography.

Philadelphia Guardians for the Relief and Employment of the Poor of the City of Philadelphia," The Accounts of the Guardians of the Poor, reprinted in Poulson's American Advertiser, May 19, 1802

Pitkin, Timothy. [1816] 1967. A Statistical View of the Commerce of the United States. Reprint, New York: Augustus Kelley

Price, Jacob. 1974. "Economic Function and the Growth of American Port Towns in the Eighteenth Century," Perspectives in American History, VIII, pp. 121-186.

Rothenberg, Winifred B. 1992. From Market Places to a Market Economy: The Transformation of Rural Massachusetts, 1750-1850. Chicago: University of Chicago Press.

Rothenberg, Winifred B. 1992. "The Productivity Consequences," in R. Gallman and J. Wallis, American Economic Growth and Standards of Living before the Civil War. Chicago: University of Chicago Press.

Shepherd, James. 1970. "Commodity Imports" (mimeo) Purdue University Working Paper

Shepherd, James, and Samuel Williamson. 1972. "The Coastal Trade of the British North American Colonies, 1768-1772." Journal of Economic History 32: 783-810.

Smith, Billy G., 1981. "The Material Lives of Laboring Philadelphians, 1750 to 1800.” William and Mary Quarterly, $3^{\text {rd }}$ ser., 38, no. 2 (April), pp. 164-202.

Soltow, Lee. 1989. Distribution of Wealth and Income in the United States in 1798. Pittsburgh, Penn.: University of Pittsburgh Press. 
Soltow, Lee, and Aubrey Land. 1980. "Housing and Social Standing in Georgia, 1798." The Georgia Historical Quarterly 64: 448-58.

Steckel, Richard. 2002. "A History of the Standard of Living in the United States," EH.Net Encyclopedia, Robert Whaples, ed. (July 21). http://eh.net/encyclopedia/article/steckel.standard.living.us .

Taylor, George R. 1964. "American Economic Growth before 1840: An Exploratory Essay." Journal of Economic History 24: 427-44.

Towne, Marvin, and Wayne Rasmussen. 1960. "Farm Gross Product and Gross Investment in the Nineteenth Century." In William Parker, ed., Trends in the American Economy. Studies in Income and Wealth, vol. 24. Princeton, N.J.: Princeton University Press.

U.S. Department of Agriculture. 1942. "Fuel Wood Used in the United States, 1630-1930." Circular no. 641. Washington, D.C.: U.S. Government Printing Office.

Vickers, Daniel. 1996. "The Northern Colonies: Economy and Society, 1600-1775," in Stanley L. Engerman and Robert E. Gallman, eds., The Cambridge Economic History of the United States, vol. 1, The Colonial Era (Cambridge, Eng: Cambridge University Press, 1996), 209-248.

Votes of Assembly, Pennsylvania Archives, Series 8, Vols. VI, VII, and VIII.

"The Walker Expedition to Quebec, 1711." 1953. The Publications of the Champlain Society. Toronto, pp. 251-54.

Weiss, Thomas. 1992. "U.S. Labor Force Estimates and Economic Growth, 1800 to 1860." In R. Gallman and J. Wallis, eds., American Economic Growth and Standards of Living before the Civil War. Chicago: University of Chicago Press.

Weiss, Thomas. 1993. "Long Term Changes in U.S. Agricultural Output per Worker, 18001900." Economic History Review 46: 324-41.

Weiss, Thomas. 1994. "Economic Growth before 1860: Revised Conjectures." In Thomas Weiss and Donald Schaefer, eds., American Economic Development in Historical Perspective. Stanford, Cal.: Stanford University Press. 